\title{
Changes of Community Orientation of Banjarmasin City from River to Land in the XX Century
}

\author{
Wisnu Subroto ${ }^{1^{*}}$ Melisa Prawitasari ${ }^{1}$ \\ ${ }^{1}$ History Education Department, Faculty of Teacher Training and Education, Lambung Mangkurat University, Indonesia \\ ${ }^{*}$ Corresponding author.Email: wisnu.subroto@ulm.ac.id
}

\begin{abstract}
The life of urban communities with the dynamics that surrounds has undergone a cultural transformation over time. The cultural transformation that is sometimes so fast makes the orientation of the people change too. These changes are related to technology that continues to penetrate society through everyday thinking and behavior. The openness of the Banjar people to foreign cultures has occurred since the entry of Europeans began to colonize and exploit areas in the interior of Kalimantan. Banjarmasin as the center of trade in Kalimantan became the focus or penetration of the invaders to change the orientation of its society through education and the application of technology. The historical method is used to extract data and facts from events left by historical actors, both in the form of writing and relics that they have used. Even recordings in the form of documentary films can be used as historical evidence that must be interpreted. This method has steps that can be verified. First looking for and collecting data to make assumptions, second criticizing the sources obtained and third writing or historiography. The change in the orientation of the people of the city of Banjarmasin can be traced through a historical study. Chronological writing of history can clearly describe urban society undergoing cultural transformation through education and technology from time to time.
\end{abstract}

Keywords: Change, community orientation, city.

\section{INTRODUCTION}

The city of Banjarmasin is geographically located in the southern part of the island of Borneo. The southwest part of Banjarmasin is the Barito river which extends to the south coast. The upstream of the Barito river is in the interior of Kalimantan and empties into the Java Sea. This river has a length of $900 \mathrm{~km}$, an average width of 800 meters and an average depth of 8 meters [1]. This area is a swampy area. There are two types of swamps, namely tidal and non-tidal swamps. Tidal swamps stretch along the banks of the Barito River and its branches, while non-tidal swamps are located in the upper reaches of the Barito River. From this upstream area, forest, agricultural and plantation products are brought to Banjarmasin through the Barito river. The area of the city of Banjarmasin which is one meter below sea level includes tidal marshlands. This lowland is used as a settlement for residents of the city of Banjarmasin along the banks of the Barito river and its branch, the Martapura river. The houses are shaped on stilts and face the river as a veranda or front yard of the houses [2].

The city of Banjarmasin is fed by the Barito river which is the main river with its branches, such as the Martapura river, the Kween river, the Awang river, the Alalak river, the Kelayan river, the Miai river, and the Andai river [3]. The name of the village in the city of Banjarmasin is also the same as the names of the rivers that flow in the city area. The flow of these rivers is an environment of interest for the city of Banjarmasin. The Barito River is the entrance to the city of Banjarmasin and the port. The main port in the XIX to mid-XX centuries was located on the Martapura river after the era of President Soeharto, the port was moved to the Barito river [4]. This river flows through marshy land that divides the city to the village of Mantuil.

The story of the formation of the city of Banjarmasin from generation to generation is believed to have been shaped by the villages around the Banjarmasin city area until now. The story is still stored in the collective memory of the people of Banjarmasin city. The story of the past can still be witnessed from the archaeological remains that lie along the rivers [5]. The city of Banjarmasin, which is located on the island of Borneo, is often called the "city of a thousand rivers" until recently.

The existence of rivers in Kalimantan affects the naming of villages, both on the riverbanks and in the interior areas. This shows that the river is a major aspect in the life of the people of Banjarmasin city [6,7,8]. Hundreds of kilometers from the city of Banjarmasin to the hinterland, you can find cities that use the term river in its name, such as Muarabahan, Muara Teweh, Kuala Kurun, Tumbang Lahong. The words Muara, Kuala, Tumbang, indicate that the city was originally a port, when the sea was still under Muara Teweh. Currently, near the sea there are Kuala Pembuang, Kuala Kapuas and Muara Bahan in the upstream area of the Barito river. In the upstream area, you can find the villages of Muara Tapus, Muara Muning and Muara Rampiau. In the city of Banjarmasin, there are names of places that have now become villages or settlements, such as Lokbaitan (bay), Teluk Tiram, Teluk Dalam, Teluk Masjid, Bilu River, Andai River, Kween River, Mesa River, 
Kelayan River and so on [9][10]. As in everyday life, when people go to the river they say they go to the sea, and go to the cliffs of the river they are said to go ashore.

The river as a transportation route is the lifeblood of daily life as a transportation route, communication between cities and villages and between cities along the river to the upstream area and vice versa. Every day these rivers are filled with local types of transportation such as jukung pangkuh, mining, Bagiwas, tiung, telangkasan, steps and sudur (Majalah; Tropisch Nederland, 1939).

Seeing the face of the city without seeing the face of the village as forming the city is very unfair. This is because cities are composed of different social structures. The villagers were often portrayed in the newspapers as a source of crime and disease. However, in the informal sector, their role cannot be ignored. Their services are often used by European citizens and Banjar merchants to work as domestic helpers and child caregivers. Kampung in the city of Banjarmasin has a different character seen from the occupation and communal ties of the residents as well as the shape of the building [11].

Between one house and another before there was a road connected by a footbridge. If there is no bridge as a link, they use the jukung as their means of transportation. The houses are located on the riverbank in the form of stilts and facing the river. This type of ironwood was chosen as the material for making houses, because this type of wood is resistant to water and does not easily rot. The roof is made of ironwood called shingles, and some are made of sago palm leaves, called thatch. See the photo in the following:

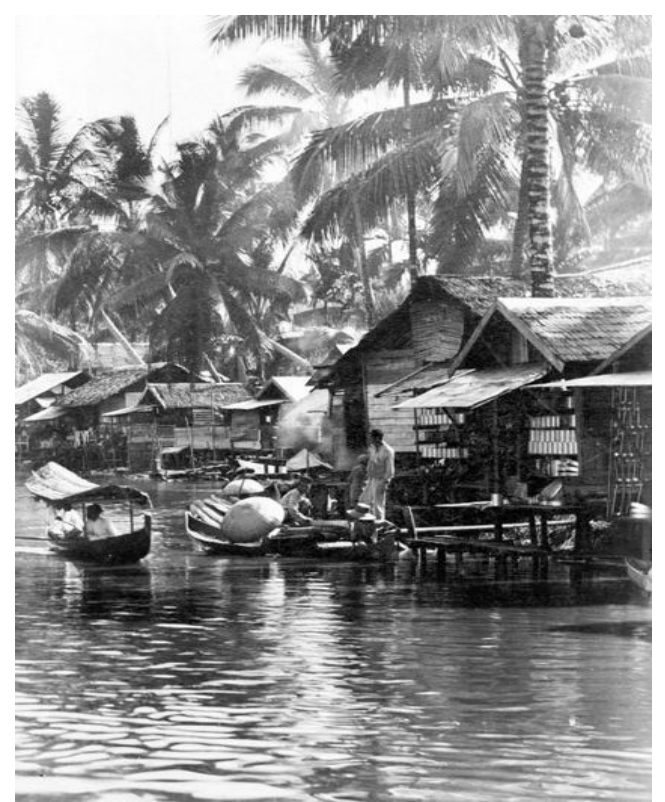

Figure 1 Banjar Society in the River

Source: Collectie_Tropenmuseum, no; 10014670

During the Dutch colonial era, the existence of these villages was maintained by the Dutch and some were forced to move according to their ethnicity. The transfer was aimed at sharpening the grouping into 3 groups, namely the indigenous group, the foreign eastern group and the European group. Likewise in education, the Dutch government established schools according to their designation, there were grade 1 schools, grade 2 schools, MULO, HIS and others. This was done by the Dutch colonial government to change the orientation of river life as a vein, which was embedded in the collective memory of the people of Banjarmasin city. In addition, the land culture that was instilled in some urban communities with a western model of education began to enter and influence their behavior to follow these changes in western culture.

From the prologue above, the focus or purpose of this writing seeks to reveal a chronological sequence of historical events. So that we get a complete picture of why and how the people in Banjarmasin have changed their orientation in seeing the river as the spirit of life. In addition, it also examines the causes of the changes in collective behavior. From these two focuses, a historical overview will be obtained regarding the change in the orientation of the people of Banjarmasin city.

\section{METHOD}

Historical research relies on data sources. Sources of data used as main information are data which are relics of the past because they contain explanations of human activities in accordance with the research theme. The source is so important that the heuristic is used as the first stage of the historical research method. Without this data source, historical research would not be possible. In summary, this research plan is realized through three stages of research, namely collection of sources, interpretation and writing. This resource gathering will be carried out in several places. In Banjarmasin, namely the Lambung Mangkurat Museum, which has a large collection of photographs, documents, books on Banjar history and reports of residents and subordinates during the Dutch administration. There are three sources that are the main material of this research, namely archives, relics of the Dutch era and newspapers. These sources were produced and published during both colonial rule and after independence. Archive sources are needed to reveal government activities in Banjarmasin especially regarding correspondence and decrees. Sources of photos or relics are used to strengthen the historical narrative described in historical writing. Resources in the form of books are used to support this research. Archive sources are needed to reveal government activities in Banjarmasin especially regarding correspondence and decrees. Sources of photos or relics are used to strengthen the historical narrative described in historical writing. Resources in the form of books are used to support this research. Archive sources are needed to reveal government activities in Banjarmasin especially regarding correspondence and decrees. Sources of photos or relics are used to strengthen the historical narrative described in historical writing. Resources in the form of books are used to support this research. 


\section{DISCUSSION}

\subsection{Changes in the Dutch Colonial Age}

The early 1900s were marked by the existence of schools that collaborated with Dutch missionaries, by establishing Catholic schools. In Banjarmasin, this Catholic school was established in the quite densely populated area of Kelayan (as one example). The Kelayan area was chosen because of its easy access to other areas (villages in Banjarmasin) by water or land. Through a modern school like this the Dutch government planned to fill the shortage of an educated and skilled workforce that could be controlled and directed according to the colonialist's wishes to perpetuate colonial rule.[10,11]. The emergence of this indigenous elite changed their perspective or orientation towards changes in the environment that affected their previous daily life.

With the defeat of the Banjar people in 1905 in the Banjar war, the area of South Kalimantan was fully controlled by the Dutch Colonial Government by consolidating into the government (Kolonial Verslag 1905)[14]. The rapid cultural transformation imposed by the Dutch colonialists. The Dutch forced residents to move houses from the riverbanks to the land. This method was taken to facilitate consolidation in regulating and grouping the population according to ethnicity[15]. The results of education in schools established by the Dutch government helped facilitate this program. The thoughts instilled in schools have succeeded in changing the orientation of city people to participate in the development of a more modern and orderly city. In addition, the Netherlands can easily find cheap labor. As an effort to smooth the consolidation, the Dutch government built road roads (Colonial Verslag 1916, 1924, 1925, 1926). Since then people living in the city of Banjarmasin have moved their houses from the riverbank to the land, facing the main road and no longer facing the river. The drastic change is where people's houses turn their backs to the river, which previously served as front porches, now they are behind the houses[16]. Overland roads connecting villages and cities in South Kalimantan have begun to be built with local workers. The city center began to build a road extending from the edge of the Martapura river which connected Pasar Baru, the Dutch village, Tatas Fort and the Old Market. New roads are starting to be traversed by city residents walking barefoot, women wearing headgear from heat and rain (Tanggui in the banjar language), becoming a new sight for the face of Banjarmasin city. In the 1920s, the development of bicycle and car technology began to penetrate the people of Banjarmasin. The vehicle importers came from Ford and Benz factories. City people are no longer walking barefoot, they are starting to learn to ride bicycles and driving a car as a more modern lifestyle. Ownership of a new means of transportation has made some urban residents to increase their social status, because not all city residents own luxury items such as cars and bicycles. For the owners of these objects, the ownership of ships as transportation for activities and means of transportation is common in their view. Not to be left behind, those who are well off also send their children to enter grade 1 and grade 2 schools, even continuing to the MULO education level (Meer Uitgebried Lager Onderwijs) and Kweekschool and above (Kolonial Verslag 1927, 1928). Ownership of ships as transportation for activities and means of transportation is common in their view. Not to be left behind, those who are well off also send their children to enter grade 1 and grade 2 schools, even continuing to the MULO education level (Meer Uitgebried Lager Onderwijs) and Kweekschool and above (Kolonial Verslag 1927, 1928). Ownership of ships as transportation for activities and means of transportation is common in their view. Not to be left behind, those who are well off also send their children to enter grade 1 and grade 2 schools, even continuing to the MULO education level (Meer Uitgebried Lager Onderwijs) and Kweekschool and above (Kolonial Verslag 1927, 1928).

The development of civil administration in Banjarmasin and the establishment of grade 1 and grade 2 schools is to provide adequate workforce in government agencies such as the Post Office, Telegraph, Health and Medical Services, Tax and Finance Office and others. In addition, developing plantation, shipping / shipping companies also need personnel skilled in administration. This process gave rise to a new class, namely the westernized bureaucratic elite who came from priyayi and also village immigrants who had received a modern / western education in grade 2 . The people of Banjarmasin who received a western education had an ambivalent attitude. On the one hand, they reject the west because they think they are destroying the old traditional order and on the other hand.

\subsection{Changes in the Japanese Colonial Age}

During the Japanese occupation, there was little infrastructure development or even said no development at all because the Japanese military government focused more on the Asian war. However, the development of human character in the Japanese era underwent a 180 degree change while still in the Dutch colony. Especially the youth. Youths aged 17 years and over are educated in the military and state defense. This is comprehensive for youth in the archipelago, including those in Banjarmasin. All energy was devoted to the Asian war, so that infrastructure development was almost non-existent.

The most important change during the Japanese period (1942-1945) was the use of Indonesian as an everyday language in life (a film about Japanese propaganda in Banjarmasin was titled Nanpo Hodo, no.13). As the language of instruction and unity of various ethnic groups, this change is accepted by the people of Banjarmasin who are very plural. The disparities that occurred during the Dutch era became increasingly fluid due to mutual understanding in the unity of language. Discrimination in education that occurred during the Dutch colonial period did not happen again, because everyone was given the freedom to go to school. Although given the freedom to attend school, the people of Banjarmasin are an ethnic group with a merchant spirit. So it is not easy to persuade to go to school.

\subsection{Changes from the Age of Independence to the Old Order}

The physical revolution in South Kalimantan with the capital city of Banjarmasin as the center of the activities of a pluralistic society, has become the strength capital to 
defend the independence of the Indonesian nation. City society forged with a trading mentality, can prove a high sense of nationalism by proclaiming that it remains integrated with the Indonesian state on May 17, 1949. This historical fact is valid evidence of a struggle and sacrifice from the urban community.

The formation of armed struggle organizations in South Kalimantan as the embryo of ALRI Division IV (Gerpindom, BPRK, BPPKI, Laskar Hisbullah, Germeri, BKR, PBM, Laskar Syaifullah), is the progress of a society that is starting to dare to show its existence in the state through an organization. military. After the return of the Unitary State of the Republic of Indonesia, consolidation into the military was mainly aimed at regulating the newly formed regional government. The implementation of development is still focused on the management of forest and mining products, which are a continuation of the results of the exploitation of the Dutch colonial era.

Significant changes in the people of Banjarmasin city from 1950 to 1959 , namely the development of wantilan (sawmill) in the Alalak area, which was previously located in the Kelayan area. The flow of urbanization from the upstream to the downstream area has increasingly attracted them to change professions from farmers to timber entrepreneurs. In addition, large companies developed in Banjarmasin with the most up-to-date machining technology in the 1950s[15,16] One of them, the Plywood company Hendratna in 1953, participated in enlivening the timber business in Banjarmasin. The existence of urban communities as traders has gradually shifted. Small and medium factories and businesses need workers to run their machines. There has been a distortion in the people of Banjarmasin city, those who used to be free to trade with flexible or unscheduled time have now become factory workers to become workers who have to comply with factory regulations with a predetermined work schedule and a set salary.

Construction of facilities and infrastructure at this time experienced a bottleneck, due to instability in the socioeconomic sector in the city of Banjarmasin. However, urban people are increasingly accustomed to following changes in the natural environment and are more inclined towards land as the basis of life, in addition to rivers which are still used in their activities as part of a hereditary culture.

\subsection{Changes in the New Order Era}

The continuation of an era full of turmoil so that a more intensive consolidation is needed to change thoughts and even river "culture" into land culture. When the government was led by General Soeharto as President of the Republic of Indonesia. The outline of policies regarding education is the expansion and distribution of educational opportunities, improving the quality and welfare of educators, and empowering educational institutions. Educational institutions are the center of the culture of values, attitudes and abilities. In addition, the aim of education development is to reform and strengthen the education system, including curriculum reform and implementation of education decentralization. Decentralization of education including curriculum reform, improving the quality of educational institutions in the face of developments in science and technology and the arts, and human resource development as early as possible. During the New Order era, education improved so that the proportion of those who were illiterate decreased.

The government has built many elementary schools (SD) to senior high schools in all regions, both districts and cities in Indonesia. The city of Banjarmasin is no exception, where the construction of schools is so fast. The aim of education is indeed to be educated, but as a result, many high school graduates only become laborers to fill jobs in industries that require manual labor. The big question for the author is whether that was the way education was like that during the New Order government? Where will you be after graduating from school? This big question the writer asks respondents who have attended high school, between 19702000, The answers from 87 out of 100 respondents in the city of Banjarmasin are traders and timber factory workers scattered in the outskirts of Banjarmasin along the Barito river. This is like a recurring incident back to the Dutch colonial era, where the government provided grade 1 and grade 2 schools to meet the needs of lowly laborers.

These factory workers do not only come from within the city, but they also come from the upstream area of the river (Ramli Nawawi, 41). The development of factories in the suburban area of Banjarmasin has led to urbanization. Many of these urbanites have tried their luck in the urban areas of Banjarmasin in search of a stable job. The urban establishment is what causes the urban landscape to change rapidly. Many rivers began to lose their function and there were public housing, housing for the middle and elite classes. So that the construction of interconnected roads in the city is designed and made to facilitate mobile land transportation modes. Slowly but surely, people who previously moved from one area to another using water transportation are now switching to using land transportation modes.

Modern housing forms and limited land availability have made housing developers in the city maximize existing land by making houses close together. This causes heat in the houses and how to overcome this by installing fans and Air Conditioner (AC). The architectural development of houses in the city also gives color to its citizens. The perspective of the people of Banjarmasin city towards their city which is changing rapidly, they respond with a more consumptive way to buy goods with modern technology.

The more facilities that are built by the government and the private sector, the faster the urbanization will flow (Ramli Nawawi, 43). The city of Banjarmasin at that time could not keep up with the flow of urbanization so that city planning became increasingly difficult. The area that used to be a swamp is now a residential area with connected land roads. The connection and information obtained by the city community is also getting faster with the presence of radio and television. There are heterogeneous urban communities that are responsive to change and some are slow to face change. 


\section{CONCLUSION}

The changes that are produced by a thought and the influence of technology in life also changes the steps of humans as cultured creatures. These thoughts enter through schools that aim to "educate". Outside of school, technological developments also have a big influence on the perspective and behavior of the people of Banjarmasin towards the developing culture. Educated urban communities are able to intertwine with technological developments.

\section{REFERENCES}

[1] DFL and EJ van Kley, Asia in the Making of Europe, volume III: a Century of Advance. London: Univercity of Chicago Press, 1993.

[2] M. \& WS Mansyur, Sahang Banjar, Banjarmasin in the $18^{\text {th }}$ Century World Spice Trade Route. Banjarmasin: Banjarmasin City Government, 2019.

[3] IS Ahyat, "Politics and Economy of Banjarmasin Sultanate in the Period of Expansion of the Netherlands East Indies Government in Indonesia, 1826-1860," 2012.

[4] B. Subiyakto, "River Cruise Infrastructure: Banjarmasin City 1900-1970," in Kota Lama Kota Baru History of Cities in Indonesia Before and After Independence, Yogyakarta: Waves, 2005.

[5] P. Bellwood, Prehistory of the Indo-Malaysian Archipelago. Jakarta: Gramedia Pustaka Utama, 2000.

[6] J. Race,Hikajat Banjar a Study in Malay Historiography. Martinus Nijhoff: The Hague, 1968.
[7] R. Broesma, Handel en Bedrijf in Zuid en OostBorneo. Gravenhage: Naeff, 1927.

[8] C. Bock, Reis in Oost en Zuid Borneo. Van Kutai naar Banjermasin ondernomen op last der Indische Regering in 1879 en 1880 . Gravenhage: Martinus Nijhoff, 1887.

[9] E. Susilowati, "The Tides of People's Boat Voyage at the Port of Banjarmasin, 1880-1990," 2004.

[10] GY Fong, "Trade and Politics in Banjarmasin, 1700-1747," 1969.

[11] H. Sjamsuddin, Historical Methodology. Yogyakarta: Ombak Publishers, 2012.

[12] R. Van Niel, The emergence of the Modern Indonesian Elite. Jakarta: Pustaka Jaya, 1984.

[13] MI Saleh, History of Thematic Areas of the National Awakening Period (1900-1942) in South Kalimantan. Banjarmasin: Research and Recording of Regional Culture, 1981.

[14] AG Usman, History of Political, Economic, Trade and Islamic Development. Banjarmasin: University of Lambung Mangkurat Press, 1976.

[15] JT Lindblad, Between Dayak and Dutch, Economic History of East and South Kalimantan. Jakarta: KITLV in collaboration with Malang: Lilin Persada Press, 2012.

[16] MI Saleh, Overview of the Banjar area and its river until the end of the 19th century. Banjarbaru: Museum Negeri Lambung Mangkurat, Province of South Kalimantan, 1983.

[17] A. Artha, History of the City of Bandjarmasin. Banjarmasin: Museum Lambung Mangkurat, 1970.

[18] AHK Bondan, Torch History of Kalimantan. Banjarmasin: Fadjar, 1953. 